Тетяна ПІЧУГІНА,

orcid.org/0000-0002-7000-2357

кандидат філологічних наук,

доцент кафедри зарубіжної літератури

Дніпровського начіонального університету імені Олеся Гончара

(Дніпро, Україна) taniaeugen@gmail.com

\title{
ФОРМУВАННЯ ПРИНЦИПІВ ЕПІЧНОГО ТЕАТРУ В ОБРОБЦІ Б. БРЕХТА «ЖИТТЯ ЕДУАРДА ІІ АНГЛІЙСЬКОГО»
}

У статті досліджується формування принщипів епічного театру в ранній п'єсі Брехта «Життя Едуарда II Англійського». Вивчення иієї n'єси актуальне, позаяк корелює з такими проблемами сучасного брехтознавства, як методи й стратегії переосмислення класичного претексту й значення обробок у творчості Б. Брехта.

Мета статті - визначення формально-змістових трансформачій, яких зазнав текст трагедії К. Марло в обробиі Б. Брехта, а також аналіз поетики «Життя Едуарда II Англійського» в контексті формування принципів епічного театру.

Порівняння n’єс К. Марло й Б. Брехта дозволяє зробити висновок, щุо останній, використовуючи образ короля Едуарда II, створив нову, сучасну n'єсу, де зробив акиент не на суперечливому коханні короля та його фаворита, а на війні, голоді й боротьбі шляхетного Мортімера й короля. Робота над n'єсою «Життя Едуарда II Англійського» була пов'язана з боротьбою проти патетичної фальші, хибної урочистості, котра десятиліттями нашаровувалася на класичну літературну спадщиину й стала ї̈ невіддільною частиною. Ранній Брехт трактував «обробку» як «політичну актуалізацію, усунення психологічного й тим самим редукцію до суспільно-типового». Використання заголовків сиен, де розкривається час і хід подій, включення пісні торговия баладами, акцент на соиіальному походженні окремих персонажів, а також інше в порівнянні з оригінальним текстом трактування образів протагоністів, щчо суперечить очікуванням глядача, відповідають цььому завданню. За принципами епічної драматургї̈ розбудовується $і$ композиція твору: життєвий шлях героїв показаний поетапно, в низиі відносно самостійних, хронологічно послідовних картин. Таким чином, аналіз обробки «Життя Едуарда II Англійського» дозволяс твердити, щзо елементи епічного театру формуються вже в домарксистський період творчості Б. Брехта.

Ключові слова: німецька література ХХ століття, епічний театр, Бертольт Брехт, обробка, ефект очуження.

Tetiana PICHUHINA, orcid.org/0000-0002-7000-2357

Candidate of Philological Sciences,

Associate Professor at the World Literature Department Oles Honchar Dnipro National University (Dnipro,Ukraine) taniaeugen@gmail.com

\section{THE DEVELOPMENT OF THE PRINCIPLES OF EPIC THEATER IN BRECHT'S ADAPTATION “THE LIFE OF EDWARD II OF ENGLAND”}

The article deals with the development of the principles of epic theater in Brecht's early play "The Life of Edward II of England". The investigation is of scientific relevance as it correlates with the contemporary research of Brecht's legacy in two aspects: firstly, it concerns the most discussed problems of the place of the adaptations in Brecht's work; secondly, Brecht's method of revising the classic pre-text is illustrated here. It must be taken into account that in Marlowe's tragedy adaptation the principles of epic theater were to worked out and put into practice for the first time.

The aim of the paper is to describe the contents transformations of the pretext in Brecht's adaptation, as well as the analysis of the poetics of "The Life of Edward II of England" in the context of the development of the principles of epic theater.

The analysis results in: Bertolt Brecht creates the distance to the pre-text by removing the overly pathetic Marlowe's drama and dissolving the unambiguity of the title character. The early Brecht understands "adaptation" as a "re-function, political actualization, dismantling of the psychological, and thus reduction to the socially typical" and thus polemically differentiates himself 'against the bourgeois addiction to originality". The use of scene titles, the references to the timing of the events and their duration, up to the inclusion of the song by ballad salesman or the emphasis on the social origin of individual characters, as well as the different evaluation of characters compared to the original text, the expectations of the audience contradicts, serve that purpose. The analysis illustrates that Brecht first steps and the development of the elements of epic theater are not to be connected with Marxism, but rather with his pre-Marxist period.

Key words: $20^{\text {th }}$ century German literature, epic theater, Bertolt Brecht, adaptation, alienation effect. 
Постановка проблеми. Значна частина драматичних творів Бертольта Брехта - це обробки відомих, а іноді й маловідомих літературних сюжетів. 3 наголошенням великої ролі обробок у творчості Брехта в сучасному брехтознавстві виникає проблема їхньої дефініції. Адже, як зауважує В. Віттковськи, «обробку, новотвір і контрпроєкт» (Brecht-Handbuch, 2001: 13) іноді важко розрізнити. До того ж неможливо звести обробки до якогось спільного концепту чи шляхом зіставлення тексту й претексту виявити якийсь певний метод Брехта в обробці первинних сюжетів (Brecht-Handbuch, 2001: 14).

Вибір обробки Б. Брехта «Життя Едуарда II Англійського» ("Leben Eduards des Zweiten von England”, 1923) як об'єкта пропонованого дослідження зумовлений низкою причин. Створена в співавторстві з Ліоном Фейхтвангером, ця п’єса $\epsilon$ також першим режисерським досвідом Б. Брехта. Саме під час обробки й постановки трагедії Марло був вироблений такий важливий прийом епічного театру, як ефект очуження (в роботі «Короткий опис нової техніки акторського мистецтва, викликаної ефектом очуження» (1940 рік) Брехт посилається на постановку саме цієї п'єси (Брехт, 1977: 63); в іншому місці він називає цей твір «технічною студією» (Thomsen, Müller, Kindt, 2006: 55)). Таким чином, аналіз обробки «Життя Едуарда II Англійського» дозволяє вивчити джерела епічного театру, визначити специфіку інтертекстуальності, колективної творчості й історизму Б. Брехта, а також сприяє розв'язанню деяких спірних питань, пов'язаних із жанром обробок у творчості драматурга.

Аналіз досліджень. Розмови про «смерть» Брехта почалися ще в сімдесяті роки. Макс Фріш заявив про «незаперечну втрату впливовості» (durchschlagende Wirkungslosigkeit) класика Брехта (Brecht-Handbuch, 1980: 1), а святкування 3 нагоди вісімдесятиріччя письменника стали приводом остаточно розпрощатися 3 ілюзіями, актуалізованими в його п'єсах. Падіння соціалістичної ідеології після Повороту, на перший погляд, взагалі позбавляло п'єси Брехта будь-якої актуальності (Brecht-Handbuch, 2001: VII). Проте «скасування політичних суперечностей» привело до протилежних результатів: західне літературознавство нарешті відкрило багатогранність і своєрідність творчості письменника, почало звертати увагу на експериментальний характер його п'єс i постановок (Brecht-Handbuch, 2001: VII). Як зауважує Я. Кнопф, саме те, за що Брехта критикували - плагіат, колективна творчість, відкриття нових форм впливу на глядача (насамперед це стосується ролі музики й кінематографу в його постановках), - стало предметом загального захоплення та відкрило нові обрії вивчення творчості режисера й драматурга Брехта (Brecht-Handbuch, 2001: VII). Сучасні західні літературознавці розглядають інтертекстуальний та інтермедіальний аспекти його драм, зосереджують увагу на мовних експериментах і специфічному історизмі Брехта. Іншого тлумачення набуває і так звана «ангажованість» брехтівського театру. «Тим, що Брехт розумів свої твори як «продукти часу» й називав їх «пробами», він привніс у літературу категорії змінювання та змінюваності, тим самим поставивши під сумнів - чи то спростувавши - такі традиційні літературні поняття, як «вічні цінності», «(гармонійна) завершеність» або «автономія», а також надав своєю концепцією відкритого твору нових вимірів літературі» (Brecht-Handbuch, 2001: VIII).

На початку XXI століття змінюється ситуація і в українському брехтознавстві: з'являються нові переклади творів Брехта - 2009 року під науковою редакцією О. С. Чиркова вийшов перший український переклад «Навчальних п'єс» Б. Брехта (перекладач - Л. О. Федоренко), через рік - переклад «Тригрошової опери», «Матінки Кураж» і «Життя Галілея» (перекладачі - М. Л. Ліпісівіцький, С. Ф. Соколовська, В. П. Прищепа), 2011 - переклад першої п’єси Брехта «Біблія» (перекладач - М. Л. Ліпісівіцький); з 2006 року в Житомирському державному університеті імені Івана Франка проходять «Брехтівські читання»; 2011 року вийшов «Брехтівський часопис» (Брехтівський часопис, 2011). Запропоновані українськими науковцями дослідження наочно демонструють, наскільки суперечливою постаттю був Б. Брехт, який сприймався сучасниками то як геній, то як об'єкт пародії.

Мета статті - визначення формально-змістових трансформацій, яких зазнав текст трагедії К. Марло в обробці Б. Брехта, а також аналіз поетики «Життя Едуарда II Англійського» в контексті формування принципів епічного театру.

Виклад основного матеріалу. Першою з обробок Бертольта Брехта була п'єса «Життя Едуарда II Англійського», сюжет якої був запозичений у К. Марло. Обробку історичної хроніки сучасника Шекспіра, надмірно громіздкої за формою та перенасиченої сюжетними лініями, Брехт у співпраці $з$ Л. Фейхтвангером здійснив для Мюнхенського камерного театру. Режисером постановки п'єси був сам Брехт, саме в ній уперше були втілені принципи епічного театру, теорія якого сформується протягом наступних п'яти років. Робота над цим твором була пов'язана з боротьбою проти 
патетичної фальші, хибної урочистості, що десятиліттями нашаровувалась на класичну літературну спадщину й стала їі невіддільною частиною. «Ми хотіли, - писав пізніше Б. Брехт, - допомогти створенню вистави, яка б зламала сценічну традицію німецького Шекспіра - той гіпсово-монументальний стиль, який $є$ таким дорогим міщанському серцю» (Брехт, 1967: 9). Фотографії вистави, декорації свідчать про реалістичне ставлення Брехта до Англії середньовіччя - «холодне, примітивне, мужицьке, без жодних ознак естетизації та куртуазності» (Брехт, 1967: 9).

Через своє особливе ставлення до театру й театральної дії Брехт досить кардинально переробив п’єсу Марло. За підрахунками Джона Віллета, «лише двадцята частина тексту була прямо перекладена Брехтом із Марло» (Willet, 1964: 15). Драматург зробив хроніку Марло більш місткою, випустив деякі образи й сцени, аби зробити п'єсу близькою до епічного театру й сконцентрувати глядача на головних «вагомих» подіях. Так, простежуючи лінію зв'язків героїв, Брехт залишив лише одного фаворита короля Едуарда - Гевестона, в той час, як у К. Марло їх було двоє: Гвестон i Спенсер Молодший, який був фаворитом короля Едварда II після смерті Гевестона. У Марло Гевестон був вигнанцем дворазово, в той час, як Брехт вирішив, що фаворит короля буде вигнаним лише один раз. Він також опустив такі фабульні елементи, як подорож королеви до Франції, заручини фаворита короля та його племінниці.

Очуження претексту спостерігається уже в назві обробки. У виданні 1594 року трагедія К. Марло відповідно до традицій часу має назву "Troublesome Reign and Lamentable Death of Edward the Second, King of England, with the Tragical Fall of Proud Mortimer” («Неспокійне правління та жалюгідна смерть Едуарда II Англійського, а також трагічне падіння благородного Мортімера»). Брехт уже в назві «Життя Едуарда II Англійського» випускає слова «смерть» і «правління», тим самим зміщуючи акценти 3 політики (правління) та смерті на «життя» Едуарда II.

Брехта цікавить насамперед, як життя великої людини призводить до смерті багатьох. Цю думку висловлює Мортімер у своїй промові в Палаті лордів, коли описує наслідки нерозумного вчинку Париса, що призвів до загибелі Трої: "Vor jemand sich's versah in folgenden Tagen / Griffen vieler Hände nach vieler Hälsen / Von zerbrochenen Schiffen spießte man viele auf / Ertrinkende, wie Thunfische. Bei zunehmendem Mond / Fehlten viele in den Zelten, in den Häusern / Wurden viele gefunden ohne Köpfe. Die Krebse / Wurden sehr feist in jenen
Jahren in dem Fluß / Skamander, aber nicht gegessen. Spähend / Nach Wetterstrich früh / Bekümmert einzig, ob Abends Fische anbeißen / Fielen gegen Mitternacht in Verwirrung und Absicht / Sämtliche" (Brecht, 1988: 21).

Кілька разів Мортімер повторює слово "viele" (багато), маючи на увазі вояків і мирних жителів, які вбивали один одного й загинули через примху Париса. У фінальному рядку ці "viele" (багато) перетворюються на "sämtliche" (всі). Це слово наголошене тим, що є єдиним словом вірша, воно резюмує головну думку промови Мортімера: через примху одного загинули всі.

Брехт вдається до подвійного очуження: його персонаж Мортімер очужує історію Троянської війни, пристосовуючи ії до конфлікту між перами й Едуардом, пророкуючи загибель всіх через небажання короля відмовитися від «ЕлениГевестона»; Брехт очужує трагедію Марло, висуваючи на перший план актуальну для його часу проблему маленької людини, адже через рішення можновладних осіб мільйони загинули в окопах Першої світової війни, стали жертвами інфляції та повоєнної розрухи.

Саме це наголошується в назві попередньої сцени: «Розруха в державі за правління короля Едуарда в 1307-1312 роках. Поразка у війні 3 Шотландією через безвідповідальність короля». Наслідки впертого небажання Едуарда відмовитися від Гевестона відчутні вже на початку сцени. Про це розповідає продавець балад у пісні "Eddis Kebsweib hat einen Bart auf der Brust" (Brecht, 1988: 14): через пристрасть короля гинуть тисячі солдатів. Вулична пісня стилістично контрастує із промовою Мортімера (якщо в пісні Гевестон названий полюбовницею Едді з бородою на грудях, то в промові Мортімера він порівнюється 3 Єленою Прекрасною, тим самим класичний образ знижується), проте за змістом і народна пісня, і пишномовна метафора Мортімера однакові: щоб один міг жити, всі повинні вмерти. До того ж Єлена й Гевестон стають невільною причиною тривалого кровопролиття та невільною жертвою кохання знатної персони. Брехт наголошує на останньому, зараховуючи Гевестона до багатьох: якщо в Марло він належить до знаті, то в Брехта $\epsilon$ сином різника. Саме це найбільше дратує перів: "Wenn im Sankt James-Spital der liebe Gott / Aus Mangel an Mehl einhundert Schweine / Eingehen läßt, stören wir deshalb Euch / Gewiß nicht von Euren Büchern, Mortimer. / Doch wenn in Westminster solch ein Schwein sich sielt..." (Brecht, 1988: 16). Сотня свиней, що «здихає» в шпиталі Святого Джеймса через відсутність хліба, - це 
солдати. Називаючи Гевестона свинею, архієпископ наголошує на його приналежності до цих жертв корони. У Марло поява солдат у першій сцені $є$ передвістям насильницької смерті Гевестона від рук солдат, у Брехта ця сцена тематизує роль солдатів у війні. Все, що отримує солдат від Англії, - сплачений шпиталь Святого Джеймса, де він здихає (verreckt). Гевестон цинічно зазначає: "Verrecken ist Soldatenlos" (Brecht, 1988: 10).

Так, уже з перших сторінок у п’єсу Брехта входить тема війни й долі солдата, що стануть провідними в його драматургії. Саме в розробці цієї теми німецький драматург найбільше відходить від претексту й наближає ренесансний текст до сучасності. Солдати представлені в п’єсі як безлика маса, що підкреслюється їхньою сценічною презентацією: в епізодах Кіллінгсвортської битви вони виступають у білому гримі, їхні обличчя позбавлені, таким чином, будь-якої індивідуальності, вони маршують із барабанами, їхні рухи механічні. Солдати нагадують механізми, що підкорюються чужій волі. Перетворюючи солдат на механізми, Брехт наголошує на новій якості війни, що також стала безликою, відколи почали використовувати катапульти: "Seit Katapulte, an denen Menschen hängen / Unaufhaltsam stampfen, seit Pferdeherden / Mit Volk darauf, scheu von Trommeln, auf- / Einander rasen... / Seit Katapulte arbeiten, Trommeln trommeln, / Bemenschte Pferdeherden / Einander auffressen, zieht roter / Taumliger Mond Vernunft aus Hirnen und aus / Dem Menschen tritt nackt der Tier" (Brecht, 1988: 31).

Допоки Едуард виступає втіленням держави, його жертви певною мірою уподібнюються: і Мортімер, і Гевестон, і королева Анна, й звичайні солдати стають жертвою непередбачуваних рішень короля. Едуард «інструменталізує», «опредмечує» людей. Гевестон та Анна $є$ для нього предметами. Як маленька дитина, що бажає отримати улюблену іграшку, він на всі резони й погрози відповідає: "Ich will Gaveston haben" (дослівно: «Я хочу Гевестона») (Brecht, 1988: 11). Едуард програє битву через те, що замість того, щоб приймати рішення та думати про відданих йому людей, він милується білявим волоссям Гевестона. Тому Едуард сприймає слова Мортімера, що Гевестон "jetzt aus der Streit ist" (Brecht, 1988: 38), як "aus der Welt ist” (Brecht, 1988: 39), і ця помилка стає фатальною для його фаворита. Анну він прямо називає своєю річчю: "Ein Ding, überantwortet testamentarisch / Seid ihr mir eigen. Mir verschrieben, unerwünscht / Ohne mein Einverständnis nie frei" (Brecht, 1988: 37). Саме ці слова призводять до зради королеви, вона укладає союз із Мортімером і перетворюється на «вовчицю», яка не буде знати спокою, доки не помститься чоловікові. Анна - єдиний персонаж у п'єсі, хто не керується розрахунком, хто насправді не жадає влади, не хоче покласти на себе відповідальність за державу, а лише турбується про власну дитину. Саме це призводить її до трагічного фіналу. Здатність забувати, яку Ніцше визначив як необхідність, за матеріалістом Брехтом, є, здається, єдиною провиною Анни. Королева Брехта $\epsilon$ не королевою, а жінкою, в той час, як у Марло Ізабелла від самого початку $\epsilon$ насамперед властолюбною та честолюбною королевою.

Якщо в Марло любовний зв'язок між Ізабеллою та Мортімером існує від самого початку п’єси, то в Брехта Анна 3 огидою говорить про своє приниження. Зауважимо, що ці слова вона промовляє «про себе», тобто не лицемірить, як Ізабелла, коли вона говорить про своє кохання до чоловіка й водночас радиться з Мортімером, як того знищити. Анна перетворюється на зрадницю під впливом підступності й честолюбства Мортімера. I якщо Ізабелла наприкінці трагедії Марло стає маріонеткою в руках свого коханця та, незважаючи на прохання сина, погоджується зі стратою Кента, то Анна Брехта своїм рішенням замінює страту на вигнання. Коли Мортімер умовляє королеву вбити Едуарда, Анна «сміється над порожнечею світу», що має підкреслити не тільки душевний стан героїні - безсилля, втому, усвідомлення своєї гріховності, а й безглуздість двірських інтриг, підлість людської природи.

Проблема «оречевлення» людей актуалізує сучасну Брехтові проблему індивідуалізму буржуазії Веймарської республіки, що висуває на перший план власні інтереси й живе коштом суспільства. У цьому сенсі деполітизація драми Марло обертається на свою протилежність: Брехт доводить, що тотальний індивідуалізм також має політичне значення, позаяк визначає політику й цинічно реалізується коштом «маленьких людей». Перша світова війна призвела до тяжких економічних і моральних наслідків, проте водночас сприяла розквітові воєнної індустрії. П'єса, написана в так звані «золоті двадцяті» - часи розквіту розважального буму, - стала свого роду попередженням суспільству. Індивідуалізм, жага розваг призводять до фатальних наслідків. Не дивно, що, опредмечуючи людей, використовуючи їх задля власної втіхи, Едуард надалі сам перетвориться на таку річ, яку будуть передавати 3 рук у руки й використовувати у власних інтересах. 
На прикладі Мортімера й Едуарда Брехт розкриває один із провідних мотивів свого твору - свідомого вибору власного падіння. Едуард, незважаючи на попередження перів, обирає Гевестона, війну й смерть. Сповідуючись єпископу, він говорить, що силою стягнув подушне з голодних рибаків, через примху затримував Анну в Лондоні спекотного серпня, через зловтіху відпустив Мортімера. Названі всі вороги Едуарда - народ, королева, Мортімер - він створив їх власноруч. Мортімер уже на початку твору передбачає свою долю, але все ж таки включається в політичну боротьбу. Мало того - обидва майже нічого не роблять задля власного життя. Едуард після поразки при Гарвічі залишається в Англії, потім попри всі знущання відмовляється зректися трону, з якоюсь маніакальною наполегливістю жадає смерті від руки Мортімера. На що той не безпідставно заперечує: "Ich seh Euch roh verstrickt in Euer Selbst" (Brecht, 1988: 82). Мортімер також відмовляється рятувати власне життя, просити про помилування Едуарда III, надаючи перевагу смерті. Саме ці два образи зазнали найбільших змін у трактуванні Брехта.

В англійського драматурга Мортімер Молодший $\epsilon$ уособленням макіавеллівської людини: «Використовуючи суспільну думку, військову міць баронів, улещуючи народ, макіавелліст Мортімер захоплює трон» (Марло, 1961: 33). Незважаючи на слабкість Едуарда II, його егоїзм і потурання власним пристрастям, симпатії читача все ж на його боці. Едуард $\epsilon$ жертвою інтриг Мортімера й баронів, які його слабкістю користуються. Король сам визнає, що причиною і його падіння, i загибелі його фаворитів $\epsilon$ те, що він керувався не потребами держави, а власним почуттям.

Інакше в Брехта: Едуард II $\epsilon$ жертвою власної мстивості, самодурства, пихатості й хтивості. Він зовсім не піклується про справи держави, на догоду своїм примхам нехтує обов'язками й словом. Так, він повертає Гевестона з вигнання, незважаючи на слово, яке дав батькові перед смертю; на повідомлення перів про смуту в країні, про загрозу від зовнішнього й внутрішнього ворога він відповідає: «Мені потрібний Гевестон». Як зауважує Е. Шумахер, «Брехт продовжив у цій роботі тему потрапляння однієї людини під абсолютний вплив іншої, цього разу в цій ролі опиняється король, чиє «я» ніби розчинюється у волі розбещеного Гевестона. Характерно, що фігура короля збільшувалася завдяки його надзвичайному приниженню» (Schuhmacher, 1981: 47-48). Щоб помститися за свого фаворита, Едуард зовсім нешляхетно обманює лордів і вбиває їх. Протягом драми Брехт доводить: слову Едуарда не можна вірити.
На відміну від архієпископа, який переслідує особисті цілі, Мортімер відмовляється від життя книжника й письменника й включається в політичну боротьбу, керуючись інтересами держави. Він добре розуміє наслідки свого втручання в політику, коли відповідає архієпископу: "Wollt Ihr am Ätna Eure Suppe kochen? / Ihr seid am Falschen. Wer anfängt / Einen Hahn zu rupfen, ihn zu essen, oder / Weil sein Gekräh gestört hat, solchen kann am Ende / Gesättigt, aus Geschmack am Schinden, Lust ankommen / Abzuziehn die Haut dem Tiger. Seid $\mathrm{Ihr} /$ Das eingedenk?" (Brecht, 1988: 17).

У Марло Мортімер Молодший, досягнувши своєї мети, насолоджується перемогою, яка недвозначно передвіщає кривавий терор: "The prince I rule, the queen do I command, / And with a lowly conge to the ground, / The proudest lords salute me as I pass; / I seal, I cancel, I do what I will. / Fear'd am I more than lov'd; - let me be fear'd, / And when I frown, make all the court look pale" (Marlowe).

Смерть Едуарда II була потрібна Мортімеру для того, щоб закріпити свою владу: він знає, що живий король може стати причиною чергового заколоту, адже навіть стражники співчувають нещасному монарху. Тому, хоча Мортімер отримує зречення Едуарда, він віддає наказ убити короля. Таке злодійство обурює читача й, безперечно, підкреслює, що Мортімер - тиран і зрадник. У Брехта наказ про вбивство пов'язаний із небажанням Едуарда віддати корону й мотивований політичною необхідністю: на думку Мортімера, це дасть можливість завершити криваві міжусобиці й зупинити зовнішнього ворога.

У Брехта Мортімер тричі намагається добитися від Едуарда зречення, удаючись і до хитрощів (розмова з єпископом), і до жорстокості (приниження та виснаження короля братами Герні), i, насамкінець, до спроби переконати Едуарда самостійно (на відміну від хроніки Марло, Мортімер Брехта сам розмовляє з Едуардом). Марність цих зусиль змушує його віддати наказ про вбивство короля.

У Марло фінальні слова Мортімера підкреслюють його честолюбство й жагу влади: він не жалкує про свої злочини й зрадництво, а гордовито заявляє, що досяг вершини: "Base Fortune, now I see, that in thy wheel / There is a point, to which when men aspire, / They tumble headlong down: that point I touch'd, / And, seeing there was no place to mount up higher, / Why should I grieve at my declining fall?- / Farewell, fair queen; weep not for Mortimer, / That scorns the world, and, as a traveller, / Goes to discover countries yet unknown" (Marlowe). 
Хоча Мортімер Брехта також говорить про примхи Фортуни, він адресує свої слова Едуарду III, змушуючи юного короля задуматися про закони життя та місце людини у світі: ““s ist, Knabe, die schlumpichte Fortuna treibt's / Ein Rad. 's treibt dich mit nach aufwärts. / Aufwärts und Aufwärts. / Da kommt ein Punkt, der höchste / Von dem siehst du / 's ist keine Leiter, 's treibt dich nach unten. / Weil's eben rund ist. Wer dies gesehn hat, fällt er / Knabe, oder läßt er sich fallen? Die Frage / Ist spaßhaft. Schmeck Sie" (Brecht, 1988: 89-90). Герой попереджає Едуарда III про небезпеку зловживання владою, адже страта Мортімера й ув'язнення матері, напевне, не $\epsilon$ найкращим початком царювання, цей перший крок може стати не лише першим кроком до вершини, а й першим кроком у прірву. Власне, виходячи з динаміки характеру Мортімера, можна твердити, що Брехт у своїй обробці трагедії Марло доводить: будь-яка влада розбещує людину, одноосібне панування не може бути справедливим i призводить до страждання народу.

На нашу думку, Брехт переосмислює конфлікт трагедії Марло, висуваючи на перший план проблему ролі особистості в історії, співвідношення особистих амбіцій і громадського обов'язку, влади й відповідальності. Людина - чи то володар, чи то пересічна особистість - не може стояти осторонь суспільних проблем, на неї покладається відповідальність за власний вибір - служити правді чи собі. Тому в Брехта зазнають поразки й Мортімер, і Едуард, і Анна.

Висновки. Порівнюючи п'єси К. Марло й Б. Брехта, можна зробити висновок, що останній, використовуючи образ короля Едуарда II, ство- рив нову, сучасну п'єсу, де зробив акцент не на суперечливому коханні короля та його фаворита, а на війні, на голоді й на боротьбі шляхетного Мортімера й короля. Звичайно, дати, час і дійові особи є правдивими, але атмосфера $є$ іншою: пишні середньовічні палаци замінені на холодні, похмурі провулки, жалюгідні халупи, брудні підвали й тому подібне., зовнішньо королі й лорди нічим не відрізняються від звичайних селян і ратників, обличчя вельможних осіб спотворені їхніми ницими пристрастями, так само як їхня мова рясніє грубою, низькою лексикою. Моделювання конфліктів у п'єсах також відрізняється: Брехт карає короля не за розпусні зв'язки, а за його надмірний індивідуалізм, за його нехтування бідними помираючими від голоду людьми. Початок репетицій «Життя Едуарда II Англійського» збігся з путчем, який організував у листопаді 1923 року Гітлер разом із Людендорфом. Ця подія додала актуальності обробці Брехта, оскільки наводила на думки про сучасні проблеми Німеччини.

Надзвичайно важливим фактом для Брехта було також те, що предметом його творчого інтересу вперше стала - як він сам писав - «оповідна манера єлизаветинської драматургії - зародження нової сценічної мови» (Брехт, 1967: 12). Надалі саме в п'єсах єлизаветинців, зокрема в їхніх хроніках, Брехт бачив прообраз тієї епічної драматургії, яку він теоретично розробляв і здійснював у своїй творчості. У цьому сенсі досвід роботи над хронікою Марло й уважне вивчення шекспірівської драматургії стали для Брехта важливими віхами на його шляху до епічного театру.

\section{СПИСОК ВИКОРИСТАНИХ ДЖЕРЕЛ}

1. Брехт Бертольт. Обработки. Москва : Искусство, 1967. 506 с.

2. Брехт Бертольт. Про мистецтво театру. Київ : Мистецтво, 1977. 365 с.

3. Брехтівський часопис (Brecht-Heft): статті, доповіді, есе : збірник наукових праць (філологічні науки). Житомир : Житомирський університет імені Івана Франка, 2011. № 1. 173c.

4. Марло Кристофер Сочинения. Москва : Художественная литература, 1961. 665 с.

5. Brecht Bertolt. Stücke 2. Frankfurt am Main : Suhrkamp, 1988. 482 S.

6. Brecht-Handbuch: in fünf Bänden / hrsg. von Jan Knopf. Bd. 1. Stücke. Stuttgart; Weimar : Metzler, 2001. XVIII. $661 \mathrm{~S}$.

7. Brecht-Handbuch. [1], Theater : eine Ästhetik der Widersprüche / Jan Knopf. 1980. 488 S.

8. Marlowe. Christopher Eduard the Second. URL: https://www.bartleby.com/46/1/ (дата звернення: 26.11.2020).

9. Schuhmacher Ernst Leben Brechts. Berlin : Henschel Verlag, 1981. 443 S.

10. Thomsen Frank, Müller Hans-Harald, Kindt Tom. Ungeheuer Brecht. Eine Biographie seines Werks. Göttingen : Vandehoek \& Ruprecht, 2006. 330 S.

11. Willet John Das Theater Bertolt Brechts: eine Betrachtung. Frankfurt am Main : Rowohlt, 1964. 267 S.

\section{REFERENCES}

1. Brecht Bertolt Obrabotki [Adaptations]. M.: Iskusstvo, 1967. 506 p. [in Russian].

2. Brecht Bertolt Pro mystetstvo teatru [About the art of theatre]. K.: Mystetstvo, 1977. 365 p. [in Ukranian].

3. Brechtivskyi chasopys (Brecht-Heft): statti, dopovidi, esse [Brecht's magazine (Brecht-Heft): articles, reports, essays]. Zhytomyr: Zhytomyr Ivan Franko University, 2011. № 1. 173 p. [in Ukranian].

4. Marlowe Christopher Sochineniia [Oeuvre]. M.: Khudozhestvennaia literatura, 1961. 665 p. [in Russian]. 
5. Brecht Bertolt Stücke 2. Frankfurt am Main: Suhrkamp, 1988. 482 S. [in German].

6. Brecht-Handbuch : in fünf Bänden / hrsg. von Jan Knopf. Bd. 1. Stücke. Stuttgart; Weimar: Metzler, 2001. XVIII, 661 S. [in German].

7. Brecht-Handbuch. [1], Theater : eine Ästhetik der Widersprüche / Jan Knopf. 1980. 488 S. [in German].

8. Marlowe Christopher Eduard the Second. URL: https://www.bartleby.com/46/1/ [in English].

9. Schuhmacher Ernst Leben Brechts. Berlin: Henschel Verlag, 1981. 443 S. [in German].

10. Thomsen Frank, Müller Hans-Harald, Kindt Tom. Ungeheuer Brecht. Eine Biographie seines Werks. Göttingen: Vandehoek \& Ruprecht, 2006. 330 S. [in German].

11. Willet John Das Theater Bertolt Brechts: eine Betrachtung. Frankfurt am M.: Rowohlt, 1964. 267 S. [in German]. 